\title{
AIR SOVEREIGNTY AND NO-FLY ZONES
}

\author{
Agus Pramono \\ Faculty of Law Diponegoro University Semarang, Indonesia \\ pramonoagus1955@gmail.com
}

\begin{abstract}
Sovereignty of a state in essence is an embedded, basic element of a state as a supreme power. However, the sovereignty of a state can only be applied within its own borders, where outside of its own territory the sovereignty of another country takes over. This research was carried out based on the approach of current legal regulations and review of literature. The study showed that airspace sovereignty is, in principle, embedded to a state of which ownership is exclusive in nature. No-fly zones are airspace in which a sovereign state determines to be restricted for flight traffic based on the existing international and national regulations.
\end{abstract}

Keywords: State sovereignty, No-fly zone, International law

\section{Introduction}

The sovereignty and jurisdiction of a state is a subject of paramount importance among the international community. Each state possess a natural sovereignty which is embedded to it, since sovereignty is a fundamental element of a state.

The sovereignty of a state extends as far as the territory of the state itself. Outside of its border, a state does not have sovereignty, so the definition ${ }^{133}$ of sovereignty as supreme power has two important limitations namely that sovereignty is valid only within the territory of the respective state and that sovereignty of a state is no longer legible within the border of another state.

Issues concerning sovereignty also include demarcation of air and space territorial borders. This issue has been a source of constant discussion due to the

\footnotetext{
133 Sovereignty in international relations between States depends on the willingness of each State to compromise the national interests of each said State.
} 
fact that until today, there is no clear boundary between air and space territories. The demarcation of air and space territory is important to avoid international conflict pertaining the matter.

Jurisdiction $^{134}$ is a reflection of the sovereignty of a state. Without sovereignty, a state would have no jurisdiction. Jurisdiction assumes that each state is equal and that between them there must not be any intervention in domestic matters.

Air territory is an important part of the elements of sovereignty of a state, other than land and sea territories. Many states have claimed their air territories under which their land and air territories are located. However, early in the development of human civilization, air borders had received little attention compared two the other two other territories since the technological and science development at the time on air, flight, or aviation had not been sufficient.

Wright brothers were the pioneers of aviation technology by inventing the first airplane. Since then, air territory has received considerable attention. ${ }^{135}$

The recent issue concerning air territorial borders pertains on its demarcation, whenever it is established horizontally, from a the territory or the high seas of a state, and vertically. Horizontal air border above the land is relatively clear since it is defined as air territory above the land border of a state according to the mutual agreement between two states, for example between Indonesia - Australia.

However, vertical demarcation of air territory is currently still disputed by many states due to the lack of defining international convention which regulate where air territory ends and where space territory begins. Many initiatives have been put forward to determine these limits, however none have yet to gain wide international recognition. ${ }^{136}$ As mentioned before, these initiatives are highly related to the current limitations in science and technology, particularly in space exploration.

\footnotetext{
${ }^{134}$ A state with capacity and power can easily extend its national jurisdiction beyond its borders considering indeterminancy in the International Law on the execution of jurisdiction of a state.

135 The absolute consequence of air sovereignty is the effective airspace surveillance of each state.

${ }^{136}$ Paris Convention 1910, on the matters of airspace navigation.
} 
The regulations on air territories has thus far based on a number of thoughts and concepts, both historical and philosophical, which has been conveyed by many experts on international law as well as the government of many states. According to records, the development of such regulations started from the Paris international conference on aviation in 1910.

The substance of ideas in air territory regulations always centered around two opposing views. One view stated that airspace should be free of territorial borders, where other views seek to defend the ownership of air territory of the state under which land and sea territories lie. The following discussion will study sovereignty of a state specifically to air territory and its relation to no-fly zones in the context of international law and regulations.

\section{Research Methods}

The method of this study was based on current legal regulations on air territory supported by review of literature.

\section{Result and Discussions}

According to Huala Adolf, ${ }^{137}$ jurisdiction (of a state) is power or legal authority of a country which is exerted to any person, thing or legal event within its own territorial borders. Almost similar to Adolf, Antono Cassese also define jurisdiction (of a state) as "the authority of the central government of a state to perform public function to individuals within its borders." 138

By these definitions, it can be understood that jurisdiction is a reflection of a sovereign state. Without sovereignty, a state would not be able to extend its jurisdictional authorities. Jurisdiction also create an equality between sovereign states, making intervention in domestic matters by another state a violation of the state intervened.

\footnotetext{
${ }^{137}$ Huala Adolf, Aspek-aspek Negara dalam Hukum Internasional, (Bandung: Keni Media, $4^{\text {th }}$ ed, 2011), p. 163.

138 Ibid
} 
Principles of international law displaying the correlation between jurisdiction and sovereignty of a state is summed up in a Latin expression par in parem non habet imperium. It means that all sovereign states are equal, and thus a state cannot extend its jurisdictional authority beyond its own borders.

The principle of par in parem non habet imperium, according to Hans Kelsen has three forms of definitions. ${ }^{139}$ First, a state extend its jurisdiction through its court of law to any action taken by another state, except when there is a mutual agreement regarding the matter between two states.

Second, an international court of law cannot try a state which does not recognize the international agreement upon which the court is founded. Third, the trial of a state cannot question the legitimacy of an action taken by the state within its own borders. As argued by Hans Kelsen, jurisdiction is indeed significantly affected by sovereignty.

The essence and function of sovereignty within the international community takes the utmost importance. The term sovereignty is etymologically originated from the Latin word "supramus" which can be translated viz-a-viz as "the ultimate." Each state is a sovereign in nature and thereby sovereignty is the essential characteristic of a state. When a state is deemed as a sovereign state, it means that the state holds supreme power and can use those powers de facto within its territories. $^{140}$

Sovereignty basically contains two aspects. First, the internal aspect which takes form of a supreme power to regulate any and everything within its own territorial borders. Second, the external aspect which is manifested in the supreme power to establish relations with other members of the international community and regulate everything beyond its border to the extent that is relevant to the interest of the state. ${ }^{141}$

\footnotetext{
139 Hans Kelsen, Principles of International Law, (New York: Rinehart \& Co, 1956), p. 235.

${ }^{140}$ E. Suherman, Wilayah Udara dan Wilayah Dirgantara, p. 4.

${ }^{141}$ I Wayan Parthiana, Pengantar Hukum Internasional, (Bandung: Mandar Maju, 1990), p. 294.
} 
Sovereignty of a state is legitimate as far as the border of the state extends. This means that a state holds supreme power inly within its own borders. Beyond that, a state no longer holds uncontested power. So the definition of sovereignty as supreme power contains two important limitations therein, namely: (1) sovereignty is limited to the border of the sovereign state, and (2) sovereignty ends at the border of another state. A state cannot extend exclusive jurisdiction beyond the territory of the state, and such action, when made unilaterally, can be considered as a breach in sovereignty of another state.

\subsection{The Correlation Between Sovereignty and Jurisdiction of A State}

A state can only extend its sovereignty fully and exclusively within its own borders. This territorial sovereignty possesses two aspects, namely positive and negative aspects. The positive aspect of sovereignty pertains to the nature of the exclusive rights related to the competence of a state within its own territory. The negative aspect of sovereignty lies in the obligation of a state to restrain from breach of rights of another state.

Huala Adolf argued that territorial sovereignty means the sovereignty held by a state to perform its exclusive jurisdictional function. ${ }^{142}$ On the other hand, according J. G. Starke the emergence of territorial sovereignty concepts indicated that within its borders, jurisdiction is exerted by the state to individual and people therein, excluding other states. ${ }^{143}$

Territorial sovereignty of a state include three dimensions, which are comprise of land and everything under and over the surface of the land, sea and air.

Issues related to sovereignty of a state, including their air territories, also give rise to certain problems pertaining the demarcation between air and space territories. These issues largely stem from the absence of an internationally recognized regulation which provides clear limits on air and space territories.

\footnotetext{
${ }^{142}$ Bachtiar Hamzah and Sulaiman Hamid, Hukum Internasional II, (Medan: USU Press, 1997), p.36.

143 J.G. Starke, Pengantar Hukum Internasional, Edisi Kesepuluh, (Jakarta: Sinar Grafika, 1999), p. 210 .
} 
The demarcation of air and space territories of a state is paramount since the identification of the sovereignty of a state over its air territory is significantly determined by clear limits between the two territories. In addition, clear demarcation of the such borders can avoid territorial disputes between the subjacent states.

Air territory, according to Article 1 Number (2) Regulations Number 1 Year 2009 of Indonesia on Aviation, is the air sovereignty over the land and waters territories of Indonesia. According to Article 1 Chicago Convention 1944 (Convention on International Civil Aviation), air territory is defined as an air passage in the atmosphere in which it contains enough air for an airplane to move therein by the exertion of a reaction force of the surrounding air as such that the airplane can gain lift. In the same article, it is also emphasized that each state possesses exclusive jurisdiction and authority in controlling the airspace which become its territories. Airplanes with flags of other states, either civilian or military, has no right to enter the airspace of or land within the territory of a state without prior consent from respective the state.

The definition of outer space territory is "A space outside where the atmospheric gases no longer exist and wherein lies celestial bodies such as the Moon and other celestial bodies." Outer space territory is regulated in Space Treaty 1967.

From the definitions above, it is highly unlikely that a single state can practice its rights and can extend its sovereignty beyond the limits of the Earth's gravitation, which is perpendicularly measured at 260,000 kilometers above the sea level. ${ }^{144}$ This concept stems form a classical doctrine which states "it is an obligation for a state to protect itself and such protection is deemed necessary and logical accounting the rights of the state to oversee parts of its territories."145

\footnotetext{
144 Priyatna Abdurrasyid, Kedaulatan Negara di Ruang Angkasa, (Jakarta: Center for Space Law Research, 1972), p. 14.

145 Ibid
} 
In principle, the function and application of sovereignty is limited to the border of a state. Every person and property therein or legal events taking place within the territory of a country must abide by to the sovereignty of a country to which the territory belongs.

Sovereignty contains the definition of supreme power which is exclusively held by the state. The principle which is born from the definition of territorial sovereignty states that a state must be able to execute full measures of sovereignty within its own borders.

Sovereignty and territory possess a Fauchille entanglement since territory is a fundamental concept in the perspective of international law. Montevideo Convention 1933 (Convention on the Rights and Duties of States) considers territory as one of the requirements of a state. ${ }^{146}$

Arbiter Huber, in a high-profile case of The Island of Palmas (1928), stated that, in its relation to territory, sovereignty is defined by two important characteristics of a state. The first being sovereignty is the de jure requirement for the legitimacy of a state, and second, that the existence of sovereignty indicates that the state is independent as well as serves as the function of the state.

In other parts, Huber also argued that Sovereignty in the relation between states signifies independence. Independence in regard to a portion of the globe is the right to exercise therein, to the exclusion of any other state, the function of a State."147

\subsection{The Correlation Between Sovereignty and No-Fly Zones}

Air territory are regulated in a number of international laws, such as Paris Convention 1919 (Convention Relating to the Regulation of Aerial Navigation), Havana Convention 1928 (Convention on Commercial Aviation), Chicago Convention 1944 (Convention on International Civil Aviation), Geneva Convention 1958 (Convention on Offences and Certain Other Acts Committed on Board

\footnotetext{
146 See the forth requirement or criterion of a state according to Montevideo Convention 1933 (Convention on the Rights and Duties of States).

147 J.G. Starke, Introduction to International Law, (London: Butterworths, $9^{\text {th }}$ ed., 1984), p. 152.
} 
Aircraft), The Hague Convention 1970 (Convention for the Suppression of Unlawful Seizure of Aircraft), Maritime Law Convention 1928 (United Nations Convention of the Law of the Sea), Montreal Convention 1991 (Convention on the Marking of Plastic Explosives), and Montreal Convention 1999 (Convention for the Unification of Certain Rules for International Carriage by Air).

In Paris Convention 1919 and Chicago Convention 1944, air territory is stated in the second article instead of the first. What is defined as "territory" in Article 2 of Chicago Convention 1944 is land and territorial water thereto under the sovereignty, protection and trusteeship of a state. This definition of sovereign territory, except for the mutual agreement for air transportation with Czechoslovakia and Japan, is always written within mutual agreements for air transportation ratified by the Indonesian government.

Paris Convention 1919 and Chicago Convention 1944 also do not provide clear regulation on air sovereignty above territorial waters. In this case, the demarcation of air sovereignty above territorial waters refers to international maritime laws as written in Geneva Convention 1958 or Article (2) Line (2) of Conventions on Maritime Laws 1982 which states that "The Sovereignty extends to the airspace over the territory as well as to its bed and subsoil." According to Article of Conventions on Maritime Laws 1982, sovereignty above territorial waters, which also applies to Indonesia, included therein sovereignty over airspace above territorial waters which extends to 12 nautical miles measured from the base lines.

Until recently there are still states demanding for demarcation of territorial waters up to the high seas. States demand demarcations anywhere from 3 to 200 nautical miles to the high seas. For instance, England demands 3 miles, Scandinavian states demand 4 miles, Spain demands 6 miles, the US demands 12 miles, and there are those that demand 200 miles. The demand for extended territorial waters demarcation can be understood due to the interest of coastal states in their Exclusive Economic Zones (EEZ) to exercise sovereignty over both natural 
and non-natural resources contained within. Still disagreements arise from the extend of territorial waters between states, due to the lack of solution in international law. For instance, the dispute between the United States and nine other South American states involving the western territorial waters of the US, where the nine South American states demand special territorial waters of 200 miles for Tuna catch fishing. In addition, there had been unilateral actions such as the establishment of Air Defense Identification Zone (ADIZ) which was followed by Canadian Air Defense Identification Zone (CADIZ).

Although the legality of such unilateral actions is questionable, states taking such action still defend extended air territory despite the fact that these states do not have full sovereignty within those air territories.

On the subject of air territory, the United States issued Section 101 Federal Aviation Act 1958. According to the act "United States means several States, the District of Columbia and the several territorial and possessions of the United States including the territorial waters and overlying airspace."

International convention laws which recognize the sovereignty of a state over its air territory was born between 1910 and 1918. After the Paris convention of 1910 was unsuccessful in its attempt to establish an international regulation on aviation, along with it comes the absence of an international regulation on aviation rights, and the British Empire unilaterally issued Air Navigation Act 1911. In the Air Navigation Act 1911, the British Empire claimed sovereignty over its airspace and that over its commonwealth states.

The act gave power to the British Imperial Minister of Internal Affairs to ban all flights from entering British Imperial airspace without prior consent from the empire government. The unilateral action taken by the British Empire was soon followed by other European nations which lead to an international convention, in which any sovereign state has full legitimacy over the airspace above its territories. This convention was sealed in the Paris Convention 1919. 
The formation of Paris Convention 1919 had been replaced and renewed in the Chicago Convention 1944, which is universally recognized. Article 1 of the convention re-emphasizes that each state possesses an exclusive jurisdiction and authority to control the airspace above its territories.

Airplanes from other states, both civilian and military, do not have the right to enter the airspace or land on the territory of a sovereign state without the expressed consent of the state. At the time, many states were embroiled in World War II. In this global armed conflict, many states witnessed air raids which were wrought about devastation anytime and anywhere they occurred. The pinnacle of these devastating military operations was the bombing of Hiroshima and Nagasaki, Japan by the United States in 1945.

Ever since the grievous historical event, many states became more and more aware of the importance of the air territory in their possession. This rising in awareness was also followed by increasing sensitivity on airspace violations, for instance whenever a foreign airplane trespasses the airspace of a state. The act of violating an airspace of a sovereign state can be fatal. An example of how sensitive airspace violation issues was when in 1957, an Indian military aircraft "Canberra" was shot down by Pakistan as a result of trespassing Pakistani airspace during a survey mission.

Another example of how fatal airspace violation can be came from July 1960, when United States Air Force "RB-47" was downed by the Soviet Union 3 miles off the Soviet shore. Prior to the incident, on May 1960, another USAF "U-2" was also shot down by the Soviet Union.

In the USAF "RB-47" incident, the United States defended its operation by stating that the aircraft was flying over an international airspace when it was shot down, a claim that was strongly refuted by the Soviet government, who insisted that the airplane had trespassed its air territory. ${ }^{148}$ Another high-profile case is the “Korea 007" incident over the Sekhalin island.

${ }^{148}$ Op. cit, p. 58-59. 
Article 5 of Chicago Convention 1944 places the importance of free passage rights under specific circumstances. However, the regulation was not widely recognized by many states. The background of such non-recognition pertains to the sensitivity of the air territory itself, taking into account rapid technological development in aviation which makes airspace a vulnerable target from each competing state.

Despite the sensitive nature of airspace borders, there have been instances where airspace violation did not end with a fatal incident. These occurrences largely depend on the nations, type or mission of the flight, and plane condition involved. If a plane incidentally trespassed the airspace of a friendly state, then it would be highly unlikely for any fatal incident to take place. Other situations that may end in peaceful resolutions include when an aircraft is running out of fuel, suffers from engine failure, endangered by extreme weather, or is held under armed hijacking. These situations normally lead to peaceful resolution.

In the event of airspace violation by a foreign aircraft, the sovereign state has the right to force the plane to land. A state is prohibited from directly opening fire to a trespassing airplane, particularly civilian passenger carrier. Before the open fire command is given, a sovereign state must warn the trespassing airplane beforehand. Under extreme circumstances, after warnings were issued, a sovereign state may intercept a trespassing aircraft, and when the situation has been determined to be a breach of national security, a sovereign state may shoot down the trespassing aircraft. The explanation mentioned is the underlying concept of interception.

In Chicago Convention 1944, some states put forth the idea to include five freedoms of the air in the convention charter. However, the idea was met with refusal form several other states. Due to this contesting opinions, the Chicago Convention resulted in two agreements, namely International Air Service Transit Agreement dated 7 December 1944 and International Air Transport Agreement dated 7 December 1944. Those five freedoms are:

a. First, freedom to fly across foreign territory without landing; 
b. Second, freedom to land for non-traffic purposes;

c. Third, freedom to disembark in a foreign country traffic originating in the state of origin of the aircraft;

d. Fourth, freedom to pick-up in a foreign country traffic destined for the state of origin of the aircraft;

e. Fifth, freedom to carry traffic between two foreign countries.

The first agreement, International Air Service Transit Agreement, only recognize the first and second freedom. In practice, only few states are willing to be committed to those freedoms. State government often favors initiation of bilateral agreements between states.

Article 1 of Chicago Convention 1944 is the basis of air sovereignty of a state. This convention was founded on the fact that many states recognize and accepts the rights that entails air sovereignty. Article 1 of Chicago Convention 1944 states that "The contracting States recognize that every state has complete and exclusive sovereignty in the airspace above its territory."

Over time, the article has been interpreted in a number of ways, often significantly influenced by the interest of the quoting state. At the beginning, the regulation aimed to prevent international conflict related to rights and authorities pertaining air sovereignty. However, it has also been a source of indeterminacy. In essence, the conflicting interpretation has been attributed to the dominance of the United States and the Soviet Union. Such dominance could be observed in politics, economy, military, and aviation technology. From judicial point of view, the article can also be deemed to be open-ended. Particularly on the terms "complete and exclusive", "territory", and "airspace" of which no complete elaboration was made.

It is important to note that not all of the states in the world ratified the results of the Chicago Convention 1944. The Soviet Union (now Russia), a state with advance aviation technology, has yet to be a ratifying state. Despite the lack of recognition from some states, it is generally held that the results of the convention are referred to as international regulation and law in relation to matters of air sovereignty. In light of this, the consequences of the adoption of the Chicago 
Convention 1944 is that no foreign aircraft can fly in the airspace of a sovereign state without the prior consent of the state. ${ }^{149}$

The recognition of sovereignty of a state over its airspace does not necessarily mean the closure of a national airspace to flights of aircraft from foreign state. The needs to serve international air transportation and to increase interconnectivity between states give incentives for states to connect their sovereign air territories to obtain freedoms of the air. The exchange of such rights commonly takes form in bilateral air agreements, in which exchange of the first two freedoms or the five freedoms of the air is mutually agreed upon between the participating states ${ }^{150}$. Such agreements are common for scheduled international air services.

\section{Conclusion}

Air sovereignty of a state is an integral part of the state itself of which ownership is exclusive in nature. No-fly zone is an airspace designated by a sovereign state where flying prohibition is placed based on the applicable national and international law.

\section{References}

Agus Pramono. (2011). Dasar-dasar Hukum Udara dan Ruang Angkasa. Bogor: Ghalia Indonesia.

Bachtiar Hamzah dan Sulaiman Hamid. (1997). Hukum Internasional II. Medan: USU Press.

E. Suherman. Wilayah Udara dan Wilayah Dirgantara.

Hans Kelsen. (1956). Principles of International Law. New York: Rinehart \& Co.

Huala Adolf. (2011). Aspek-aspek Negara dalam Hukum Internasional. Bandung: Keni Media.

I Wayan Parthiana. (1990). Pengantar Hukum Internasional. Bandung: Mandar Maju.

\footnotetext{
149 Agus Pramono, Dasar-dasar Hukum Udara dan Ruang Angkasa, (Bogor: Ghalia Indonesia, 2011), p. 13.

150 Ida Bagus Rahmadi Supancana, Peranan Hukum dalam Pembangunan Kedirgantaraan, (Bandung: Mitra Karya, 2003), p. 278.
} 
Ida Bagus Rahmadi Supancana. (2003). Peranan Hukum dalam Pembangunan Kedirgantaraan, Bandung: Mitra Karya.

J.G. Starke. (1984). Introduction to International Law. London: Butterworths, $9^{\text {th }}$ ed.

J.G. Starke. (1999). Pengantar Hukum Internasional. Jakarta: Sinar Grafika, $10^{\text {th }}$ ed.

Priyatna Abdurrasyid. (1972). Kedaulatan Negara di Ruang Angkasa. Jakarta: Center for Space Law Research.

Chicago Convention, 1944

Space Treaty, 1967.

Indonesian Regulation Number 1 Year 2009 on Aviation. 